\title{
sciendo
}

\section{CIVIL PROCEDURE ON SECURING A CLAIM IN THE REPUBLIC OF KOSOVO}

\author{
Bionda Rexhepi, \\ $\mathrm{PhD}$. Candidate at Civil Law, Law Faculty, \\ South East European University, Tetovo, North Macedonia; \\ Str. Mulla Idrizi, no.7, Gjilan, 60000, Kosovo \\ biondarexhepi1@gmail.com
}

\begin{abstract}
The objective of the paper is to create a concept of what securing the claim is, based on the positive legislation of Kosovo's law, comparing its regulation with laws of somewhat similar legislations of neighbouring regions, understanding its implementation in practice, to achieve conclusions and remarks based on law, facts, practice, and the comparative aspect. The Civil Procedure Law in the Republic of Kosovo is regulated with contested, non-contested or enforcement procedure. Securing the claim is an institute expressively regulated by the "Law on Contested Procedure of the Republic of Kosovo" on its XXI Chapter that defines its means and types.

Considering securing the claim measures are present in civil law to prevent any possible threat of protected rights until the final verdict is given, this paper tends to achieve a realization of how these measures practically succeed in actual cases, if they meet the criteria set in the law, or if securing the claim proposal is approved by the court, if they unintentionally restrain the respondent from using their rights. Moving forward, how one distinguishes claim security and interim measures from one-another although they describe the main concept, is strictly reviewed under this article, to finally achieve conclusions and remarks based on questions raised as above.
\end{abstract}


Keywords: Law on Contested Procedure-LCP, Law on Enforcement Procedure-LEP, Claim Security, Interim measures, CCPA-Code of Civil Procedure Albania, ECHR - European Convention on Human Rights.

\section{INTRODUCTION}

The actual realization of subjective private rights usually takes relatively long time. This is because to realize a subjective right, the recognition procedure must be developed in principle, in which the subjective private right is ascertained. And only after this procedure, the procedure of actual realization of the subjective private right should be developed, in which the execution procedure is forcibly realized by the request of the creditor. So, it usually takes a long time for the actual realization of the subjective private right. During this time, the unscrupulous debtor, who is unwilling to meet the expectation voluntarily, can use various methods to make it difficult or impossible for the creditor to realize his subjective right. Because of that, there are different rules to provide the creditor to ensure his claim security. In this regard, different legal orders provide for different institutes, through which the claims of creditors are secured. Securing creditors' claims is done through special procedures, which are in principle summary (fast) procedures. (Morina; Nikqi, 2012)

By providing the security claim to the proposer, his acquired rights are ensured until the final verdict is given. This insurance is only authorised by a judgment or somewhat other document that understands an executive document. To obtain this document, the proposer must initiate a proposal at the basic court as the procedure requires. (Qehaja, 2015, pg. 173)

A claim can be secured by different measures, also known as interim measures, selected by the Law on Contested Procedure in the Republic of Kosovo.

Interim measures are relief (also referred to as "provisional" or "conservatory" relief) that the court may grant to a party before the final judgment on the merits of the case, in order to protect the party's position or assets pending judgment. The interim measures typically take a form of an injunction restraining a party from disposing of or otherwise dealing with its assets, or from taking (or refraining from) other action necessary to ensure that a final award will be enforceable. The interim measures are most frequently requested in cases involving debt claims or property disputes in situations when the debtor threatens or intends to remove or dispose of his property to defraud his creditor or if the defendant in the suit threatens to dispossess the claimant or otherwise cause injury to the claimant in relation to the disputed property. The 
interim measures are also requested in family law cases, such as the cases of maintenance, the guardian and upbringing of children, etc. (Zoroska-Kamilovska, 2013, pg. 3)

\section{THE FIRST CLAIM SECURITY MEASURES LAND ON THE OLD ENFORCEMENT LAW OF THE REPUBLIC OF KOSOVO}

The old Law on Contested Procedure did not regulate this institute; rather it was regulated by the old Law on Execution Procedure (LEP). The old LEP has decisively provided by this law to determine the rules according to which the court acts for the mandatory execution of the court decision regarding the completing of the obligation, as well as the provision of claims and that the provisions of this law on the execution procedure are set appropriately, applicable to the insurance procedure, unless otherwise provided by the relevant provisions of this part. And with the old LEP legislation three types of measures as security measures have been envisioned: establishment of mortgage in real estate, precautionary measures and temporary measures. (Morina/Nikci, 2012, pg. 541)

"Peculiarities of the measures provided for by LCP (Yugoslavia 1978), were that the two measures before as the pledge on real estate and preliminary measures, besides general conditions that had to be met, such measures could be defined only when the creditor's request was confirmed by the court judgment which yet was not to become final or executable, whereas the provisional measure was not limited to the existence of the court judgment, so it was possible to be submitted before, during and after the completion of the trial on the dispute." (Qehaja, 2015,pg. 173)

Next, the Law on Contested Procedure takes into account the opponent of the proposal destiny of a possible right to be damaged if the security claim by the proposer is approved, therefore it acknowledged an institute known as "bail", which should be understood as a deposit, that this deposit shall serve as a measure if any damage occurs to the opponent of the proposal. (Qehaja, 2015, pg. 173-174)

The new LCP does not clearly define the legal nature of the measures through which the claim is secured, because in fact, all the security measures that can be imposed by the courts are of a temporary nature, but which will apply and may be valid until the completion of the court proceedings, including the enforcement proceedings. (Zogaj; Leku; Totaj, Hasanpapaj; Cunniff, 2019, pg. 195) 


\section{SECURING THE CLAIM AS REGULATED BY THE LAW ON CONTESTED PROCEDURE OF THE REPUBLIC OF KOSOVO}

As can be seen from the very name of this institute, its main purpose is to ensure the realization of creditor claims. Creditor in the sense of this law should be understood as the creditor from the substantive law, ex. the subject of the right, who has the right to demand from the debtor the completing of a certain expectation. This is due to the fact that from the moment of filing a lawsuit in court until the issuance of a meritorious decision regarding that lawsuit, a long time may pass, as a result of various procedural delays. On the other hand, there may be a permanent risk that, despite the meritorious decision, the obligation set out in it will not be fulfilled, due to the subsequent subjective or objective impossibilities of the party which this decision obliges to perform any obligation. The new LCP recognizes the person who requests the court to secure his claim as the proposer of insurance, while the person against whom the insurance is imposed, this law calls only as opposing party or "opponent of insurance". (Morina/Nikci, 2012, pg. 542-543)

\subsection{Terms and conditions on claim security according to Kosovo's LCP}

When we talk about security measures, it is very important to emphasize the fact of the difference between the regulation of security measures between the new LCP and the old LPP which has regulated these measures. The old PPL, unlike the new PPL, has provided for the division of security measures into three types, such as the right of pledge on immovable property, precautionary measures, and temporary measures. In the new LPC, the legislator did not differ strictly these measures from one-another. The legislator while drafting the new LCP has taken in account that that these measures, although different with no clear division between them, they do represent the same concept of security measures, only the nature of the case can change. Therefore, LCP through this paragraph, in all cases, for any action taken by the court in order to secure the claim, calls them precautionary measures, which are in fact temporary measures. (Morina/Nikci, 2012, pg.544)

"This amount, deposited by insurance proponent, shall be refunded by court order to the proponent within 7 days from the date when insurance cases to exist, and if the opposing party files a lawsuit against the proponent of the insurance for damage compensation caused by ordering of security measure then the competent court shall decide on this lawsuit through a trial about this damage also may decide to uphold the security measure or determine the amount 
of the guarantee not to be refunded to the proponent of insurance until the end of the trial according to the claim for compensation”. (Qehaja, 2015, pg. 174)

The 7 days term to initiate the procedure in the court for compensating the damage is believed to be very short, because the respondent will possibly need more time to prepare the lawsuit for such compensation. Therefore, this term shall be amended to no shorter than 30 days. It is also believed to be a technical error taken by the old previous law that regulated this institute, because it releases the local governance from depositing a "bail", although this clearly makes no sense because the local governance shall be treated equally as any other party in the procedure before courts. (Qehaja, 2015, pg. 174-175).

Thus, arguing that point, LCP legislation regulates has manifested a short time to acquire the guarantee that causes trouble into practicing it.

\subsection{Types of securing the claim measures according to Kosovo's LCP}

The following security measures may be imposed for securing the demand for money:

a) the prohibition of the opponent of the insurance to alienate, conceal, encumber, or dispose of the certain property of sufficient value to secure the claim of the insurance proposer. This prohibition has to be registered in the relevant public register,

b) the preservation of the property to which the prohibition from the point abovementioned concerns the court in its deposit, when there is a possibility for such a thing, or by giving possession to the insurance proposer or a third person,

c) prohibiting the debtor of the insurance opponent from fulfilling the request or handing over the item, as well as forbidding the insurance opponent from accepting the item, realizing the request, or disposing of it,

d) foreshadowing the right of pledge on the immovable property of the insurance opponent, or on the right registered in the immovable property, up to the value of the main claim, with procedural and interest expenses, for which the judgment has been given which is still has not been made executable.

The ruling imposing the security measure is sent to the insurance opponent, the debtor of the insurance opponent, and when the case is the relevant public register. The security measure is considered applied at the moment when the ruling is delivered to the insurance opponent or his debtor, if it has been delivered to the latter, or to the relevant public register, depending on which of these three delivery dates is earlier in terms of time. (Law on Contested Procedure of Republic of Kosovo, no.03/L-006, article 299)

The difference between the security measure of cash claims (Article 299 of the LCP) and claims which are directed to a certain item or to a part of it (Article 300 of the LCP), is in points c and $\mathrm{d}$ of these articles. Regarding the security of claims which are directed towards a certain thing 
or towards a part of it, point $\mathrm{c}$ of this paragraph has foreseen the imposition of a measure of prohibition for the opponent of the security to perform any action, which may damage the part of the property to which the claim is directed, and also the security opponent may be assigned the security measure to be ordered to demonstrate specific actions necessary to preserve the thing or property or to maintain the actual situation of such circumstances. According to point $\mathrm{d}$, the court may determine the measure through which it authorizes the security proposer to carry out certain activities against the object of the opponent or his certain property, in order to maintain the existing situation or to prevent the damage of the objects or property of the opposing party to the insurance. Thus, point a) of this article, as a security measure has provided the prohibition of the insurance opponent to perform certain activities, the same order to perform such activities, in order to maintain the existing situation or prevent damage of the opposing party. (Morina/Nikci, 2012, pg. 551-552)

\subsection{Deciding procedure on securing measures and compensation claims according to Kosovo's LCP}

The court that the proposal on securing the claim is submitted must firstly check its jurisdiction (absolute or territorial). Jurisdiction gives court specific authorisation that another court cannot decide upon such proposal. "Case jurisdiction determines the scope of courts of different kinds and the courts of the same type but different ranking, and the main criterion for setting this jurisdiction is the subject of litigation. On the other hand, territorial jurisdiction determines the competence of a body that can act in a legal issue and is related to the territory where it conducts its activity". (Qehaja, 2015, pg. 179)

Meanwhile, Article 307 of this Law, has regulated in particular the content of the ruling which determines the security measure. In the ruling on imposing a security measure, the court determines the type of security measure. (Morina/Nikci, 2012, pg. 562)

After the decision is taken by the court to impose a temporary security measure and after the same decision is notified to the opponent of the security, then the latter may within 3 days in his response, to challenge the reasons for setting the temporary security measure. If the opponent of the security in this case justifies his objections, then the court will be forced to schedule a hearing on this issue within the next 3 days. If after holding this hearing, the court finds that the objections of the insurance opponent (the defendant) are grounded, then it may, by a special ruling, annul the previous ruling on the imposition of a temporary security measure, or to replace it with another ruling on imposing a security measure in accordance with Article 307 of this law. An appeal is now allowed against this new ruling on imposing a security 
measure. It follows that although in the case of imposing a temporary security measure, the opponent of the insurance is not given the opportunity to declare the same, or to oppose it, he has the right to express the views of the in relation to the measure provided through a written response. (Zogaj; Leku; Totaj, Hasanpapaj; Cunniff, 2019, pg. 205-206)

Article 312 of this law has regulated a negotiating or available situation where the parties (insurance proposer and insurance opponent) propose and agree on the replacement of the security measure with the creation of a pledge, or the establishment of the pledge rights on the object of the insurance opponent by the insurance proposer. Article 315 of this law guarantees the insurance proposer the right to compensation of damage, which may result as a result of non-compliance with the insurance measure. Article 316 of this law now guarantees the right to compensation of damage to the opponent of insurance. While Article 315 of this law guaranteed the right to compensation of damage to the insurance proposer, now Article 316 guarantees this right to the opponent of insurance. According to these provisions, which refer to the statute of limitations regarding the claims for compensation of damage, we have the subjective deadline which is three years from the date when the injured party learned about the damage and the person who caused it, and the objective deadline that is five years from the date the damage was created or caused. If, eventually, the claims for compensation of damages from article 315 and 316 of this law are statute-barred, then both the insurance proposer and the insurance opponent, based on the provisions of the Law on Obligations, will be able to request from the responsible person only to cede what he has taken from the action by which the damage was caused, invoking the rules that apply in the case of unjust profit. (Morina/Nikci, 2012, pg.570, 575, $576 \& 577)$

Therefore, LCP stands on its principles while deciding on matters that require quick and fast calls. That can easily be concluded by the above-mentioned articles. The complete procedure on deciding for such proposal is not an easy one, because a judge must decide on the proposal, while not prejudicing the claim itself, yet must take into consideration all the evidence of the proposal, that it is indeed related to the claim itself.

\section{SECURING THE CLAIM, AS FORESEEN ON THE CIVIL PROCEDURE CODE OF THE REPUBLIC OF ALBANIA AND DISTINGUISHES WITH THE REPUBLIC OF KOSOVO'S REGULATION}

The Code of Civil Procedure of Albania regulates the institute of "securing a lawsuit" in Chapter IV with Articles 202 to 212. In principle, the essence of such an institute is the same, 
both in the Code of Civil Procedure of Albania, as well as in the Law of Kosovo Contested Procedure, but their regulation differs from each other. The primary difference is in the voluminous aspect of the articles, where that of KPCSH contains only 10 articles while LCP contains 22 articles. The LCP also uses the term "claim insurance", which is more adequate because it worthily represents the plaintiff's proposal than the term "lawsuit insurance", which is used by the CCPA, as the lawsuit implies only the formal act. However, we also have substantive differences, where a concrete example is Article 203 of the CCPA with Article 297 of the LCP, which provide differently when security measures can be imposed. According to CCPA, security measures are allowed when:

a) the lawsuit is based on written evidence,

b) the plaintiff provides a guarantee that the court decides on its extent and type for the damage that may occur to the defendant by securing the claim. (Code of Civil Procedure Albania, 2013, Article 202)

Whereas, according to LCP, security measures are set:

a) if the insurance proposer makes it credible the claim existence for his/her subjective rights,

b) if there is risk that without providing such measure, the proposal opponent could make it difficult or impossible, or significantly hard to realize his rights, especially by alienating its property, hiding it, encumbering or in any other way, which would change the existing state of affairs, or in any other way negatively affect the rights of the claim security proposer.

Par.2 Unless otherwise provided by law, the court imposes the security measure only under the conditions that the security proposer, within the time limit set by the court, as provided by the Law on Execution Procedure, guarantees the amount and type determined by the court, for the damage that may be caused to the opposing party by imposing and executing the security measure (Law on Contested Procedure of the Republic of Kosovo no.03/L-006, Article 297/ Qehaja, 2015,pg. 17)

Using the comparative method, one can observe that LCP does not restrict the plaintiff to make a motion to secure a claim in a certain way as it does in its articles CCPA and gives more space for the plaintiff for such a motion. However, it is quite clearly stated in both legislations that a security proposer must provide a guarantee that the court decides for that guarantee.

Types of claim security measures are another case that can be compared and distinguished. While the CCPA lists the types of security measures that can be proposed in the lawsuit, the LCP does not do so, on the other side, CCPA does not issue details to further clarify about the measures, while the LCP clarifies the possibility and circumstances of using each type in separate articles. 
CCPA lists the following types of security measures for the lawsuit:

a) with the seizure of movable and immovable property as well as of the debtor's loans,

b) by other appropriate measures taken by the courts (Code of Civil Procedure Albania, 2013, Article 206).

LCP, on the other hand lists the following types of security measures:

a) securing the demand in money,

b) securing the request addressed to the certain item or to a part of it and

c) the provision of other rights or for the preservation of the existing state of circumstances. (Morina/Nikci, 2012, pg. 200)

The legislator in CCPA has given sufficient space to the judge through the second point to manoeuvre according to the request without being limited to certain means or types, while such a thing is not found in LCP. Furthermore, the LCP continues the clarification in the articles in cases if the insurance opponent does not act according to the ruling, what should be contained in the proposal for securing the claim, cases of interim measures, deadlines when the insurance opponent should be notified and others, while CCPA automatically passes to the article for appeal. "A separate appeal can be made against the decision of the court that has decided to accept the request for securing the lawsuit, for changing or removing the insurance of the lawsuit. The appeal of the above decision does not prevent the continuation of the review of the lawsuit. An appeal against a decision authorizing a precautionary measure does not suspend its execution. The appeal against the decision by which the security measure is replaced or removed, suspends its execution" states CCPA (article 209) while LCP states "Against the decision of the first instance on the security measure can be appealed within seven (7) days from of his submission. The appeal is sent to the opponent of the insurance who within three (3) days from the submission has the right to submit to the court the answer to the appeal. The appeal shall be decided by the court of second instance within a period of fifteen (15) days from the day on which the response to the appeal arrives or the deadline for its submission expires. The appeal does not postpone the execution of the ruling. An appeal is not allowed against the ruling on the temporary measure". (Article 310)

Therefore, we clearly notice the lack of deadlines in the CCPA, while regulated in the LCP and the fact that no appeal is allowed against the ruling on the interim measure in the LCP, as long as no such case is mentioned in the CCPA.

Finally, by comparing these two legislations that regulate the same institute while both these legislations fall under the same legal family, one can conclude that CCPA is more abstract and mentioned in the content of creating shortcomings for their implementation, while LCP is 
more pragmatic, voluminous, and detailed thus creating more opportunities for the realization of this right.

\section{HARMONISATION OF SECURING THE CLAIM LAW OF THE REPUBLIC OF KOSOVO WITH THE LAWS OF EUROPEAN UNION \\ The European Convention on Human Rights (www.gjk-ks.org) in Article 1 of Protocol} No. 1 provides: "Every natural or legal person has the right to respect for his or her property. No one shall be deprived of his possessions except in the public interest and subject to the conditions provided for by law and by the general principles of international law (Article 1, Protocol 1).

These provisions though do not prejudice on cases when the State has to interfere to regulate or fix property issues according to the overall interest of its people, or to fix the fines, taxes or other payment contributions. (Gommen, 2005, pg. 3)

As can be understood from this article, the institute of claim security regulated in the Law on Contested Procedure, does not constitute a violation of Human Rights and it is in accordance with the Convention.

The respect for property as referred in the Convention, commonly referred as the right to property, may be restricted only for reasons of public interest and in other conditions provided by law, one of which is securing the claim. In interpreting the term "respect" for property, both the Commission and the Court have often had to distinguish between notions of deprivation of property and the regulation of its use. Essentially, the purpose of the "restrictions" is not to deprive the property, but to regulate its use under applicable law, without infringing on the rights of any other person. Rules of Court, Rule 39 of the European Court of Human Rights foresees that any State Party of the Convention may initiate interim measures. Interim measures also known as securing the claim measures are urgent or fast measure that are applicable on situations with irreparable risk or imminent harm. To decide for such measures, a proposal goes to court by the proposer of the interim measures and the competent court gives such a decision. The proposer has to demonstrate the real risk or harming of the right he/she is facing. (Press Unit, 2020) 
Interim measures are measures in the absence of which compliance with the court decision may be rendered more difficult or impossible. In cases involving the temporary restriction of the property rights to a jointly owned item, seizure may be imposed only on that share of the property which belongs to the person subjected to the interim measures. Where his/her share in the joint property has not been identified, the entire property may be seized until that share is identified. Upon seizure of funds in accounts with banks and other credit institutions, the use of these funds is authorized only for the operations specified in the court order. In cases where goods in free circulation, raw materials, semi-manufactures, or ready-made products are seized, the property holder may change the composition and form of such property only if the total value thereof will not decrease, unless the court order provides otherwise. A person whose property has been seized is liable for any infringement of the restrictions imposed from the moment of notification of the order to seize the property and, if notification is impossible, including where the order for interim measures is adopted in the absence of that person, from the moment the order is registered in the register of property seizures. (E-justice Portal Lithuania)

Thus, Kosovo's Law on Contested Procedure is harmonized with European Union regulations and securing the claim measures are rules that European Union supports and allows.

\section{KOSOVO CASE LAW}

A case was brought to Kosovo's Constitutional Court for giving a verdict on the challenged rulings that are related to the Applicant's request for imposing a security measure against XY Company, pending the result of his main lawsuit in the contested procedure. With this verdict given by the Constitutional Court, it has unified the justice practice on how, why, and when the security measures can work on civil cases.

\section{Republic of Kosovo's Constitutional Court Verdict, Prishtine, 30 April 2018 Nr. ref.: AGJ 1226/18}

Here are some facts:

a) The Applicant has a contract number valid with more compact XY Company which provided that disputes would be dealt with by the Court of Arbitration in the Czech Republic;

b) The Applicant filed a dispute with XY Company in the Arbitral Tribunal and won the Arbitral Award in large sums of money 1,364,527.00 plus interest rates;

c) This decision of the Arbitration is final and binding;

d) This Arbitral Award and recognizes as enforceable in Kosovo by regular courts in Kosovo, both in the first instance and on appeal;

e) A valid Execution Order and issued by the Private Bailiff; 
f) This Execution Order and certified by the regular courts, in instance first and on appeal, and took final form and became enforceable;

g) Shareholders of XY Company. made a decision for dissolution volunteers of XY Company;

h) The Applicant initiated a contentious procedure against the Decision for voluntary disbandment;

i) The Applicant requested the imposition of a security measure by litigation procedures.

The subject matter of the Referral is the constitutional review of the challenged decisions, which allegedly violated the Applicant's rights guaranteed by Article 31 [Right to a Fair and Impartial Trial] and Article 32 [Right to Remedies] of the Constitution of the Republic of Kosovo (hereinafter: the Constitution), in conjunction with Article 6 (Right to a fair trial) and Article 13 (Right to an effective remedy) of the European Convention on Human Rights (hereinafter: ECHR). The Court first notes that Article 6 of the ECHR, in the civil part, applies to procedures defining civil rights or obligations. The Court further notes that the preliminary proceedings, such as those relating to issuing an interim measure / security measure - usually not are considered to define civil rights and obligations and therefore do not usually fall within the scope of such protection. However, in certain cases, the ECHR applied Article 6 of the ECHR to these pre-trial proceedings when it considered that the security measures were crucial to the Applicant's civil rights. In 2009, the ECHR deliberately reversed its previous approach to pre-trial proceedings by issuing the following statement in response to the question of whether there is a need for a development of case law: Exemption of temporary images from the scope of Article 6 it is now justified by the fact that they do not, in principle, define obligations and civil rights. However, in a situation where many Contracting States have to deal with a considerable accumulation of cases due to the overload of their justice systems, leading to protracted proceedings, a judge's decision on a restraining order often occurs that is equivalent to a decision on the merits of the case for a considerable time, sometimes forever. Consequently, it often happens that the procedures for provisional measures and those related to the main legal action decide on the same "obligations and civil rights" and give the same long-term or even permanent effects. Based on this Judgment, the Court notes that not all security measures / interim measures define civil rights or obligations and the applicability of Article 6 of the ECHR to pre-trial proceedings depends on whether certain conditions are met. First, the right in question must be "civil", in the trial, even in proceedings concerning the security measure, within the autonomous meaning of this notion under Article 6 of the ECHR. Second, the ECHR states that the nature of the interim measure / precautionary measure must be observed, since whenever such a measure is considered to effectively define the civil law or 
obligation in question - Article 6 will be applicable and it has therefore concluded that there has been a violation of Article 31 of the Constitution of the Republic of Kosovo in conjunction with Article 6 of the European Convention on Human Rights. (Republic of Kosovo's Constitutional Court Verdict, Prishtine, 30 April 2018 Nr. ref.: AGJ 1226/18, pg. 21-24)

\section{CONCLUSION AND REMARKS}

- Securing the claim purpose is to help the person claiming a right, secure that right, that can change due to different circumstances along the way.

- Securing the claim also serves as a way not to damage the person claiming a right before the courts, because of the long procedure a lawsuit usually withholds, with special emphasis in the Republic of Kosovo.

- Securing the claim causes troubles implementing it by the courts without prejudicing the claimed right.

Property right to any person, rather natural or legal is guaranteed by the law, also known as an absolute right to the owner of the property. National and international private law recognize such a right to the property owner and unless of general interest, no owner can be limited from his/her right to property and in case an owner is somehow limited, they have the right to address the court for their property rights and any other damage that may have been caused from that.

Ownership is the complete right to an item. The owner may dispose of the property at his own discretion, in particular to own and use it, to dispose of it and to exclude others from any influence, unless it is contrary to the law or to the rights of a third party. Therefore, for the protection of property rights, the legislator has issued relevant provisions, which express the path that should be followed by interested parties to ensure the necessary judicial protection by approving the Law on Contested Procedure no.03 / L-006. The court gives legal entities legal protection even in situations where there is a risk that the implementation of the civil legal sanction will not give the right result. In other words, it is granted in cases where it is likely that the subjective civil right will not be exercised despite the use of force by the competent body. In such cases, the legal protection lies in the imposition of precautionary measures provided by the provisions of the LCP. When the circumstances set by law are met, the mentioned measures can be imposed not only during the development of the contentious process, but also before its implementation. However, although we are dealing with the provision of legal protection, it should be noted that it has a temporary character. It lasts until 
the court in the contentious procedure gives the decision by which it rejects as unfounded the request for legal protection, or until the creditor realizes his credit to the debtor (Berisha, 2015, pg. 90-91).

Thus, the recommendations are to:

- firstly, adjust security claim on civil matters practice to Kosovo's Constitutional Court Verdict as above-mentioned;

- secondly, amend Article 298 as above-mentioned to change the 7 days term to no shorter than 30 days;

- thirdly, numerously line up the interim measures-security claim measures on LCP, as lined up on the former LEP of Kosovo, and

- fourthly, although one can claim for interim measures on security claim, Kosovo's positive legislation shall make a clearer division between security claim measures and interim measures,

This would help securing the claim articles achieve better success in its practice, considering the numerous problems in its implementation, both by the court and litigants, as mentioned above. 


\section{REFERENCES}

1. Berisha, I. (2015). Masat për Sigurimin e Kërkesëpadisë. Justica, revistë shkencore juridike e kandidatëve të Programit të Trajnimit Fillestar 2013/2015 në Institutin Gjyqësor të Kosovës, 90-91.

2. Civil Procedure Code Albania - Kodi i Procedurës Civile i Republikës së Shqipërisë. (2013). Gjetur në Ministria e Drejtësisë: https://www.drejtesia.gov.al/wpcontent/uploads/2017/11/Kodi_i_Procedures_Civile-2014-perf-1.pdf

3. Gomien, D. (2005). Udhëzues i shkurtër për Konventën Europiane për të Drejtat e Njeriut. Instituti Norvegjez për të Drejtat e Njeriut, Universiteti i Oslos, Botimi në shqip, përkthyer nga Hasan Bylyku.

4. Guide on Article 1 of Protocol No. 1 to the European Convention on Human Rights Protection of Property. European Court of Human Rights. (2020). Gjetur në Guide on Article 1 of Protocol No. 1 to the European Convention on Human Rights - Protection of Property. European Court of Human Rights: https://www.echr.coe.int/Documents/Guide_Art_1_Protocol_1_ENG.pdf

5. JUDGMENT, K1122/17 Applicant Ceska Exportni Banka A.S. Constitutional (Court of Appeals, of 11August 2017, and Decision IV. EK. C. No. 273/2016 of the Basic Court in Prishtina, of THE CONSTITUTIONALCOURT OF THE REPUBLIC OF KOSOVO 7 14, 2017). Gjetur në GJYKATA KUSHTETUESE: https://gjk-ks.org/wpcontent/uploads/2018/04/ki_122_17_agj_ang_.pdf

6. Kosovës, G. Z. (2008). LIGJI NR. 03/L-006 PËR PROCEDURËN KONTESTIMORE. Gjetur në Gazeta Zyrtare e Republikës së Kosovës: https://gzk.rksgov.net/ActDocumentDetail.aspx?ActID $=2583$

7. Measures, I. (2021). Press Unit - Factsheet of European Court of Human Rights. Gjetur në Press Unit - Factsheet of European Court of Human Rights: https://www.echr.coe.int/documents/fs_interim_measures_eng.pdf

8. Morina, I., \& Nikqi, S. (2012). E-Library of the Kosovo Judicial Institute. Gjetur në http://jus.igjk.rks gov.net: http://jus.igjk.rks gov.net/508/1/KOMENTAR\%20\%20Ligji\%20i\%20Procedures\%20Kontestimore.pdf

9. Qehaja, R. (2015). Ensuring the Charge Claim According to the Kosovo Law on Contested Procedure. Academic Journal of Interdisciplinary Studies MCSER Publishing, Rome-Italy, E-ISSN 2281-4612 ISSN 2281-3993, 173-179. doi:10.5901/ajis. 2015. v4n1s2p173

10. Zogaj, A., Leku, Z., Totaj, V., Hasanpapaj, B., \& Cunniff, M. (2019). Manual për Zbatim të Procedurës Kontestimore. Gjetur në Këshilli Gjyqësor i Kosovës: https://www.gjyqesori-rks.org/wpcontent/uploads/reports/72001_MANUAL_PER_ZBATIM_TE_PROCEDURES_KO NTESTIMORE.pdf

11. Zoroska-Kamilovksa, T. (2013). Interim Measures in IP Litigation from the Macedonian Perspective, Iustinianus Primus Law Review Vol. 4:1, pg. 3. Gjetur në International Arbitration Information by Aceris Law LLC: https://www.internationalarbitration-attorney.com/wp-content/uploads/1 tatjana-zoroska-kamilovska-ph-d-ef80-aainterim-measures-in-ip-litigationfrom-the-macedonian-persp.pdf 